\title{
Assessment of the Possibilities and Challenges of Shale Gas in the Global Energy
}

\section{Transition}

\author{
Avaliação das Possibilidades e Desafios do Gás de Xisto na Transição Energética Global \\ Evaluación de las Posibilidades y Desafíos del Gas de Esquisto en la Transición Energética Mundial
}

Received: 01/28/2022 | Reviewed: 02/01/2022 | Accept: 02/05/2022 | Published: 02/10/2022

\author{
Celso da Silveira Cachola \\ ORCID: https://orcid.org/0000-0003-3412-2180 \\ University of São Paulo, Brazil \\ E-mail: celsocachola@usp.br \\ Matheus Eugenio Afonso \\ ORCID: https://orcid.org/0000-0002-8457-6335 \\ University of São Paulo, Brazil \\ E-mail: matheuseugenio022@gmail.com \\ Edmilson Moutinho dos Santos \\ ORCID: https://orcid.org/0000-0003-3088-855X \\ University of São Paulo, Brazil \\ E-mail: edsantos@iee.usp.br \\ Drielli Peyerl \\ ORCID: https://orcid.org/0000-0003-4466-1284 \\ University of São Paulo, Brazil \\ E-mail: dpeyerl@usp.br
}

\begin{abstract}
The improvement of horizontal drilling techniques and hydraulic fracturing makes shale gas exploration an option economically. Shale gas has the potential to reshape energy policy at national and international levels. Shale gas development can be an effective path to a low-carbon energy transition because natural gas, conventional or unconventional, has relatively lower emissions than other fossil fuels, as well as lower cost and abundant global reserves. This paper uses the SWOT analysis method to identify possibilities and challenges that shale gas development may face. To prepare the analysis, an advanced search was carried out on the Science Direct platform, investigating the strengths $(\mathrm{S})$, weaknesses $(\mathrm{W})$, opportunities $(\mathrm{O})$, and threats $(\mathrm{T})$ of the development of shale gas linked to the energy transition context. The most cited strength was abundant availability, followed by increased energy security. Regarding weaknesses, the most evident were environmental impacts and pollution. The mostreported opportunity for shale gas development was the prospect of replacing other sources, and the threat was public skepticism and less support than there is for renewables, although the ban was also included. A possible path for the development of shale gas, in an energy transition context, is an opportunity to replace other sources, such as coal, taking advantage of its abundance and energy security. However, for development to become relatively clean, fugitive emissions and other negative aspects of exploration must be mitigated.
\end{abstract}

Keywords: Shale gas; Energy transition; SWOT Matrix; Natural gas.

\section{Resumo}

O aprimoramento das técnicas de perfuração horizontal e fraturamento hidráulico torna a exploração de gás de xisto uma opção econômica. O gás de xisto tem potencial para reformular a política energética nos níveis nacional e internacional. O desenvolvimento do gás de xisto pode ser um caminho eficaz para uma transição energética de baixo carbono porque o gás natural, convencional ou não convencional, tem emissões relativamente menores do que outros combustíveis fósseis, além de menor custo e reservas globais abundantes. Este artigo usa o método de análise SWOT para identificar possibilidades e desafios que o desenvolvimento de gás de xisto pode enfrentar. Para preparar a análise, foi realizada uma busca avançada na plataforma Science Direct, investigando os pontos fortes (S), pontos fracos $(\mathrm{W})$, oportunidades $(\mathrm{O})$ e ameaças $(\mathrm{T})$ do desenvolvimento do gás de xisto ligado à transição energética. A força mais citada foi a disponibilidade abundante, seguida pelo aumento da segurança energética. Quanto às fragilidades, as mais evidentes foram os impactos ambientais e a poluição. A oportunidade mais relatada para o desenvolvimento de gás de xisto foi a perspectiva de substituição de outras fontes, e a ameaça foi o ceticismo público e menos apoio do que há para as energias renováveis, embora a proibição também tenha sido incluída. Um caminho possível para o desenvolvimento do gás de xisto, num contexto de transição energética, é a oportunidade de substituir outras fontes, como o carvão, aproveitando a sua abundância e segurança energética. No entanto, para que o 
desenvolvimento se torne relativamente limpo, as emissões fugitivas e outros aspectos negativos da exploração devem ser mitigados.

Palavras-chave: Gás de xisto; Transição energética; Matriz SWOT; Gás natural.

\section{Resumen}

Las mejoras en las técnicas de perforación horizontal y fracturación hidráulica hacen que la exploración de gas de esquisto sea una opción económica. El gas de esquisto tiene el potencial de remodelar la política energética a nivel nacional e internacional. El desarrollo de gas de esquisto puede ser un camino efectivo hacia una transición energética baja en carbono porque el gas natural, convencional o no convencional, tiene emisiones relativamente más bajas que otros combustibles fósiles, así como un costo más bajo y abundantes reservas globales. Este artículo utiliza el método de análisis FODA para identificar las posibilidades y los desafíos que puede enfrentar el desarrollo del gas de esquisto. Para elaborar el análisis se realizó una búsqueda avanzada en la plataforma Science Direct, investigando las fortalezas (F), oportunidades (O), debilidades (D) y amenazas (A) del desarrollo del gas de esquisto vinculado a la transición energética. La fortaleza más citada fue la abundante disponibilidad, seguida de una mayor seguridad energética. En cuanto a las debilidades, las más evidentes fueron los impactos ambientales y la contaminación. La oportunidad más reportada para el desarrollo de gas de esquisto fue la posibilidad de sustitución por otras fuentes, y la amenaza fue el escepticismo público y el menor apoyo que existe para las energías renovables, aunque también se incluyó la prohibición. Un posible camino para el desarrollo del gas de esquisto, en un contexto de transición energética, es la oportunidad de sustituir otras fuentes, como el carbón, aprovechando su abundancia y seguridad energética. Sin embargo, para que el desarrollo se vuelva relativamente limpio, se deben mitigar las emisiones fugitivas y otros aspectos negativos de la exploración.

Palabras clave: Gas de esquisto; Transición energética; matriz FODA; Gas natural.

\section{Introduction}

In the last decade, the biggest change in the global oil and gas industry has been the improvement of horizontal drilling techniques and multistage hydraulic fracturing (The Academy of Medicine Engineering and Science of Texas, 2017). The advent of these new exploration techniques has made shale gas an economically attractive option, consequently increasing the consumption of natural gas (NG) in countries such as the United States (US) and Canada (Agency, 2011; Euzen, 2011). Thus began the exploration of vast shale deposits, such as Barnett and Marcellus in the US, which was previously unfeasible for production (The Academy of Medicine Engineering and Science of Texas, 2017). In addition, the rapid development of shale gas exploration significantly impacted NG production. There was a 35\% growth rate between 2005 and 2013 in NG production in the US, making the country one of the largest producers of this energy source (Chang et al., 2014; Gao \& You, 2017). Shale gas has the potential to reshape energy policy at national and international levels, even altering geopolitics and energy security (Aczel et al., 2018; Sica \& Huber, 2017). It can also reshape energy technology investment decisions and change trends in greenhouse gas (GHG) emissions, as NG can emit fewer GHGs when compared to other sources such as coal (Amec Foster Wheeler, 2015; Hultman et al., 2011).

However, the exploitation of shale gas can have impacts on human health and the environment, such as water contamination (Campbell et al., 2011; Hultman et al., 2011) and high consumption of this resource during the fracturing process (Chang et al., 2014; He et al., 2018). In addition, there may be a risk of migration of gas, formation water, or fracturing fluid through hydraulic fractures in shallow drinking water aquifers, for example (Euzen, 2011). In some cases, there is evidence that the methane $\left(\mathrm{CH}_{4}\right)$ content in water wells may increase considerably near some shale gas drilling sites $($ Osborn et al., 2011). In the case of fracturing, a process that injects pressurized water and chemical compounds into underground rocks, for example, it is estimated that a well in the Barnett shale gas in the US requires an average of 15 million liters of water during its useful life, and between $80 \%$ and $95 \%$ of them will be discarded as wastewater (Absar et al., 2018).

Another worrying factor regarding the environmental impact is the GHG emissions related to the shale gas life cycle (Absar et al., 2018; Chen et al., 2020). One of the main GHGs emitted naturally in NG production is CH4 (Bouman et al., 2015). CH4 is one of the main constituents of NG, and its emission into the atmosphere can occur at all points during the 
extraction process, that is, in the drilling and completion of wells, also in their operation, and through leaks of the entire infrastructure (Bouman et al., 2015). From a holistic perspective, it is estimated that a shale gas well in Marcellus, US, emits about 5500 tons of $\mathrm{GHG}$, or $1.8 \mathrm{~g}$ of carbon dioxide equivalent $\left(\mathrm{CO}_{2} \mathrm{e}\right) / \mathrm{MJ}$ of gas produced throughout its life cycle, representing an $11 \%$ increase in GHG emissions compared to conventional gas (He et al., 2018). It is noteworthy that this increases by an average of $3 \%$ more if we consider gas combustion (He et al., 2018).

Despite its negative environmental impacts, NG, both conventional and shale, is often demonstrated as a possible bridge to the eventual use of hydrogen in fuel cells with zero GHG emissions (Ogden et al., 2018). In liquefied or compressed form, NG also proved to be more advantageous as a replacement for other fossil fuels in the transportation sector, both in the rail modal (Dincer \& Zamfirescu, 2016) and the road modal (Khan et al., 2016). NG can be a promising source for a transition to low carbon, as it has relatively lower emissions than other fossil fuels, as well as lower cost and abundant global reserves (Aguilera \& Aguilera, 2012; Chávez-Rodríguez et al., 2017). Furthermore, NG plays an important role in the balance of energy systems, as it does not have intermittence like renewable energies (Chávez-Rodríguez et al., 2017) and they alone cannot guarantee a rapid and large-scale transition to a low-carbon matrix, being less efficient than the current dominant sources (Kerr, 2010).

Increasing the use of NG is one of the actions suggested to reduce the carbon intensity of energy systems. It can support growing energy needs with lower carbon emissions than other fossil sources (Lozano-Maya, 2016). In addition, NG can become an effective complement to renewable energies such as wind and solar energy (Lozano-Maya, 2016; K. Wu et al., 2016). Switching from coal to NG can save significant amounts of GHG emissions, particularly in the US, China, Europe, and India (IEA, 2019), and the international trade in liquefied natural gas (LNG) can provide a catalyst for a more liquid global gas market, due to flexible US LNG prices (Agency, 2011; Lozano-Maya, 2016).

Many analysts and professionals in the energy sector have argued that shale gas development can be an effective path to a low-carbon energy transition. However, unlike other fossil fuels, the concentration of NG (both conventional and unconventional) in a small number of exporting countries has been one of the biggest obstacles to the expansion of its use (EIA, 2016; Lozano-Maya, 2016), in addition to the environmental impacts already mentioned. Then, what would be the role of shale gas development in a global energy transition? What are the opportunities and challenges that its development faces in consolidating itself in the world panorama as a transition source? Thus, the main objective of this article is to analyze the context of shale gas in the global energy transition, using as a method the creation of a SWOT analysis (Strengths, Weaknesses, Opportunities, and Threats), bringing the necessary notes to analyze the panorama of the development of shale gas.

This paper comprises, in addition to its introduction, Section 2, which addresses the development of shale gas in different countries; section 3, which details the methodology and database used in this article; and section 4, which shows the role of shale gas in the transition through SWOT analysis and analyzes how opportunities can favor the development of shale gas and how threats and weaknesses can be minimized. Finally, Section 5 addresses the authors' conclusions.

\section{The Overview of Shale Gas Development in the World}

In 2013, around 31,138 Tcf of shale gas reserves were identified in the world. This value was evaluated in 41 countries, and of this total, approximately 6,634 Tcf were considered technically recoverable, not including US reserves. Including US reserves, assessed reserves increased to $35,782 \mathrm{Tcf}$ and technically recoverable reserves increased to a volume of 7,795 Tcf (U.S. Energy Information Administration (EIA), 2013). It is estimated that shale gas production in the coming decades will grow, reaching around 100 Bcf per day in 2040. In 2016, only 4 countries (US, Canada, China, and Argentina) 
had commercial production of shale gas, and in 2020 this scenario remained the same (International Gas Union (IGU), 2020). Technological improvements in the coming years are expected to encourage shale gas development in other countries, including Mexico and Algeria. The US, Canada, China, Argentina, Mexico, and Algeria are expected to account for $70 \%$ of the global shale gas production in 2040 (EIA, 2016).

In the US, shale gas production represented more than half of national NG production in 2015 (EIA, 2016). The socalled "shale gas revolution," which started in the country around 2007, increased US NG production by about $45 \%$ between 2007 and 2017 and led to a sharp drop in NG prices. As a result, NG has surpassed coal as a cheap source of electricity generation in many US regions, and the share of electricity generation from NG has increased from $22 \%$ in 2007 to $32 \%$ in 2017 (Mendelevitch et al., 2019). The beginning of shale gas exploration in the US was only possible through implementing directional drilling techniques and hydraulic fracturing (called fracking). By 2018, large-scale logging was taking place in states such as Pennsylvania and Texas. In the other US states, the proposals were beset by significant environmental and legal controversy, in some cases leading to local, regional, or state moratoria and bans, as happened in the states of New York and Maryland (Thomas et al., 2018). The "shale gas revolution" has given the US an unprecedented advantage as a producer and exporter on the global energy market. Shale gas has provided a source of resilience to the country and improved its position globally while challenging Russia's positions in all target markets, including Europe and Asia (Ganguli, 2016).

Since 2008, Canada has been producing shale gas, reaching 4.1 Bcf per day in 2015 (EIA, 2016). Shale gas production in the country should continue to increase and account for almost 30\% of NG production by 2040 (EIA, 2016). In Canada, in 2017, more than half of the oil and NG wells in the west of the country were being drilled horizontally, and since 2013, around $80 \%$ of all oil wells in production in the province of Alberta have been using horizontal drilling techniques. Fracking has been used safely in over 180,000 oil and gas wells in Alberta since the technology was introduced in the 1950s (Natural Resources Canada (NRCan), 2017a). In the province of British Columbia (BC), shale gas reserves and drilling activities are concentrated in two main basins: Montney and Horn River, and the production of these basins can represent around 20\% of shale gas production in North America (Campbell et al., 2011; NRCan, 2017b).

Another issue attributed to shale gas is the public's perception of exploration. In Canada, regional governments must consult with indigenous peoples to determine if their rights are affected during shale gas development (Thomas et al., 2018). The Government of Alberta provides policy guidance to the Alberta Energy Regulator, which regulates all oil, NG, oil sands, and coal development activities in the province. The agencies have improved policies and regulations related to water management, groundwater protection, well integrity, air quality, noise and light, and induced seismicity (NRCan, 2017a). Although shale gas exploration takes place in the provinces of Alberta and BC, fracking has been subjected to a moratorium in the eastern provinces of Canada (Quebec, Nova Scotia, and New Brunswick) (Thomas et al., 2017), due to the anti-fracking public mobilization that took place in these provinces (The Council of Canadians, 2014).

China was one of the first countries outside of North America to develop shale gas resources. Between 2011 and 2016, the country drilled more than 600 shale gas wells and produced 0.5 Bcf per day at the end of 2015 (EIA, 2016). Shale gas is expected to represent more than $40 \%$ of the country's total NG production by 2040, which would make China the second-largest shale gas producer in the world, after the US (EIA, 2016). After the "shale gas revolution" in the US, China made a major development plan for its shale gas resources, and the China National Energy Administration proposed a national development target to achieve production of around 1 Tcf of shale gas by 2020 and about 3 Tcf by 2030 (R. Liu et al., 2021). China is estimated to have about 1,115 Tcf of technically recoverable shale gas reserves, with 626 Tcf in the Sichuan basin. Chongqing, a municipality located in the Sichuan basin, had the first Chinese shale gas project. The Fuling shale gas field was discovered in 2012 and started commercial production in 2014 with several dozen wells in production (Heikkila et al., 2018). 
Shale gas exploration in Chongqing is mainly led by central and provincial or municipal governments, championed by industrial partners such as Sinopec and PetroChina, and supported by academic research institutes (Heikkila et al., 2018).

Commercial shale gas production in Argentina was 0.07 Bcf per day at the end of 2015, and the country's shale gas infrastructure is adequate to support current production levels. Still, it will need to be expanded as production increases (EIA, 2016). In 2016, Argentina had a shortage of specialized platforms and fracturing equipment. However, these technical failures should be overcome, mainly due to foreign investment in the country's shale gas development sector. It is estimated that shale gas production will represent 75\% of Argentine NG production by 2040 (EIA, 2016). The Vaca Muerta formation in southern Argentina contains large amounts of shale oil and gas, located in the provinces of Mendonza, Neuquén, and Rio Negro. However, most of it is located in the province of Neuquén (Heikkila et al., 2018). It is estimated that Argentina has a reserve of 27 billion barrels of technically recoverable shale oil and 802 Tcf of shale gas, ranking third among countries in terms of the reserve, and most of it is located in the Vaca Muerta formation (Heikkila et al., 2018). The 2010 discovery of large amounts of shale oil and gas in the Vaca Muerta formation was greeted with much enthusiasm by local authorities and the oil and gas business sector. Still, there was also great concern from environmentalists who questioned the environmental impacts of shale extraction. In 2013, the Argentine national oil company Yacimientos Petroliferos Fiscales signed an agreement with the American energy multinational Chevron to expand shale oil and gas exploration in Argentine territory. The agreement was ratified by the regional government, although there was social and political opposition to it (Costie et al., 2021).

In 2015, the Algerian government started a pilot project to explore shale gas and develop a 20-year investment plan to commercially produce the resource. Algeria's shale production is expected to represent one-third of the country's total NG production by 2040 (Azubuike et al., 2018; EIA, 2016). Algeria is the third country with the highest volume of NG exports to Europe, behind only Russia and Norway (Azubuike et al., 2018; Eurostat, 2020). In collaboration with international companies, Algeria's National Oil Company Sonatrach carried out an initial exploration of shale gas in the country. In January 2015, its first exploratory well was drilled using the fracking technique. However, commercial production was not viable until the end of the 2010s (Azubuike et al., 2018). In the face of falling NG production, depleting external revenues, and local and international demand for NG, Algeria seeks to develop its shale gas potential to avoid economic decline (Azubuike et al., 2018).

Economic diversification goals and the search for a relatively clean energy economy also lead Algeria to develop its shale gas (Azubuike et al., 2018). As for the geographic location of the reserves, shale resources overlap with conventional resources, and the Ghadames basin, which lies east of the Algeria-Libya-Tunisia border, has a recoverable reserve of around $282 \mathrm{Tcf}$ of shale gas. The Timimoun basin has a recoverable reserve of about $152 \mathrm{Tcf}$ and the Ahnet basin is estimated to have a recoverable reserve of $60 \mathrm{Tcf}$ (Azubuike et al., 2018; Boersma et al., 2015). In addition to Algeria, other countries in the Middle East and North Africa (MENA) intend to expand the development of shale gas. However, in the region, the largest assessed reserves are in Algerian territory (about 706 Tcf of assessed reserves), followed by Saudi Arabia (around 600 Tcf of assessed reserves) and the United Arab Emirates (around 205 Tcf of assessed reserves) (Griffiths, 2017).

Mexico is expanding its pipeline capacity to import cheaper NG from the US. Mexico is expected to start producing shale gas commercially after 2030 and shale reserves will contribute more than $75 \%$ of the country's total NG production by 2040 (EIA, 2016). The advent of shale gas technologies and their impact on regional economies contributed to legislative reform of the energy industry in Mexico. Legislation passed by the Mexican government in 2013 and 2014 opened up much of the energy sector to private companies and foreign investments (Alberto et al., 2018; Hudgins et al., 2016). Therefore, this historic reform created an opportunity for US energy companies. The Burgos basin is an extension of the Texas Eagle Ford shale, and this basin is estimated to contain 67\% of Mexico's recoverable shale gas reserves (Hudgins \& Lee, 2016). Fracking 
has been carried out in Mexico since at least 1980 and by 2017, approximately 3,780 wells had been drilled. The peak was reached in 2010, with 746 wells being drilled, and continued at an approximate pace until 2012 (Alberto \& Ibarzábal, 2018). Between 2012 and 2017, the number of wells gradually decreased, and in 2017 only eight were drilled. One of the main barriers to the development of shale gas in Mexico is the regulatory aspects surrounding shale exploration (Alberto \& Ibarzábal, 2018).

In European countries, the development of shale gas is uncertain. France, in July 2011, through the "Jacob Law," prohibited the exploitation of shale gas by fracking. In the society's discussions on energy transition, which took place in 2012 and 2013, shale gas was not mentioned among the resources to be possibly explored in the future. In Germany, the main objective of the current energy policy is to promote an energy transition (Energiewende) that gradually replaces fossil fuels and nuclear energy with renewable energy sources (Cantoni et al., 2018). After a few years of debate, in June 2016, the German Parliament approved a bill that allowed the fracking of conventional oil and gas resources under strict environmental conditions but did not allow the use of the technique to exploit shale resources (Cantoni et al., 2018; Herrera, 2020). In relation to Poland, the question of energy dependence is particularly sensitive, as Polish-Russian relations are not very friendly and, therefore, the main argument underlying the defense of shale gas by the Polish government was precisely a greater energy autonomy from Russian gas (Cantoni et al., 2018; Wagner, 2015). However, due to difficult geological conditions, prolonged legislative regulations, and declining oil and gas prices on the world market, the development of shale gas in Polish soil has not matured, and companies started to shut down operations in 2013 (Cantoni et al., 2018).

In the United Kingdom (UK), each country has its own fracking regulation rules. The Scottish government formalized a permanent moratorium on hydraulic fracturing for shale extraction in October 2017 (Evensen, 2018). Wales tends to follow the Scottish example by making its moratorium permanent. In Northern Ireland, since 2015, there has been a moratorium on high-value fracking. England remains the only one of the four UK nations to allow hydraulic fracturing. Among the four nations, England has the largest estimated reserves of unconventional oil and gas (Evensen, 2018). The recoverable shale gas reserves in the Nordic countries are small, and among the Scandinavian countries, the greatest potential shale gas reserves are in Sweden and Denmark. Sweden is estimated to have around 11 Tcf of recoverable shale gas reserves, and Denmark approximately $32 \mathrm{Tcf}$. In the early 2010s, the exploitation of shale gas provoked significant public concern and anti-fracking activism in the Nordic countries (Becker \& Werner, 2014), and in 2012, the Danish government stopped issuing new exploration licenses (Danish Energy Agency, 2021). In the Swedish context, shale gas exploration proved to be economically unfeasible, as its reserves are very limited (Sveriges Geologiska Undersökning (SGU), 2020; Van de Graaf et al., 2018).

Russia is estimated to have a large reserve of shale gas, a total of 286 Tcf. However, this huge amount is only $17 \%$ of the country's vast proven conventional NG reserves (1,660 Tcf). Thus, Russia will not have to worry too much about exploiting shale gas in its territory, at least in this century. Therefore, the country is currently focusing on developing its vast conventional NG reserves (Melikoglu, 2014). Despite theoretically not having to worry about the exploitation of shale gas in its soil, Russia may lose opportunities on the NG exportation market to European and Asian countries (Ganguli, 2016; Kim \& Blank, 2015). With more affordable prices, the US can export the shale gas produced in its territory to European countries, including Eastern countries and the Baltic republics (Estonia, Latvia, and Lithuania). The vast regasification plants of Spain and Portugal can be used as a route for this (Kim \& Blank, 2015).

The development of shale gas in other BRICS countries, an economic bloc formed by Brazil, Russia, India, China, and South Africa, is still incipient (except in China, as mentioned above) (Atkinson, 2018; Lenhard et al., 2018). Shale exploration in Brazil began in 1954 in the municipality of Tremembé. However, there was no further development. Thus, the exploration of shale reservoirs by unconventional means is still a novelty in the country (Lenhard et al., 2018). Hydroelectric 
power is the main source of electricity in the country. Still, starting in 2000, a period of drought pushed reservoir levels down, forcing the government to request the use of natural gas-fired thermoelectric plants without having enough national gas to feed them. Thus, Brazil is trying to reduce NG imports by exploring wells in the pre-salt basin (Melikoglu, 2014). In Brazil, the mineral resources within the land are under government control, and promising reserves for shale development are the Parnaíba and São Francisco basins (Camargo et al., 2014). It is estimated that these basins have a volume of about 288 Tcf of technically recoverable resources (Camargo et al., 2014).

In South Africa, until 2018, no shale gas well had been explored, and shale exploration was very limited, despite being much researched and debated in the country (Atkinson, 2018). There are also uncertainties regarding the exploitation of shale in the country since, until 2018, South Africa was economically stagnant. There are several groups (among them farmers and environmentalists) that oppose the development of shale gas in the Karoo region (Andreasson, 2018). In India, shale gas development is expected to reduce dependence on oil and gas imports and minimize the use of coal for power generation. There is a forecast that the demand for NG in the country will double by 2030, with shale gas being explored throughout the country. In 2011, the Raniganj basin was the first basin in India to be explored with tests carried out by the Oil \& Natural Gas Corporation (ONGC), with a well being drilled to $1,700 \mathrm{~m}$ and yielding significantly positive results (Mendhe et al., 2017). In addition to the Raniganj basin, other basins can be explored in India, including the Cambay, Krishna-Godavari, Cauvery, and Damodar Valley basins (Bellani et al., 2021). In March 2017, 22 wells were drilled for shale evaluation, with 5 wells in the Cambay basin for shale gas evaluation (ONGC, 2021).

Pakistan can be considered as one of the fifteen largest countries with shale reserves. The country's shale reserves are present in the Lower Indus Basin, located along the border of India and Afghanistan. The Baluchistan basin is considered prospective as well, but there is no estimate of shale gas for it, due to its geological complexity. Despite having the technology to explore conventional oil and gas, Pakistan does not have the know-how to explore shale resources (Raza et al., 2018). Indonesia also has recoverable shale reserves north of Sumatra. Although the risk to the environment is relatively high, shale gas development in the country may help fill the energy gap until renewable energies mature (Dutu, 2016). Australia is one of the largest holders of shale gas reserves on the planet. The development of shale gas would contribute to the growth of the country's energy market; however, the shale gas industry is at an early stage and additional exploratory activities are needed to identify commercial reserves. There are barriers to be overcome for the exploration of shale gas in Australian territories, such as regulatory, social, and environmental restrictions (Gonzalez Cruz et al., 2018).

\section{Methodology}

The methodology used in this article was organized into three steps: i) advanced bibliographic search in the "Science Direct" database, ii) creation of the SWOT matrix with the bibliographic data collected, and iii) analysis of the matrix with selected data from the previous step (see Figure 1). In this way, bibliographical references were searched and, with the data found, the SWOT matrix was filled out, highlighting the strengths, weaknesses, opportunities, and threats of the use and exploitation of shale gas. 
Figure 1. Methodological procedures.

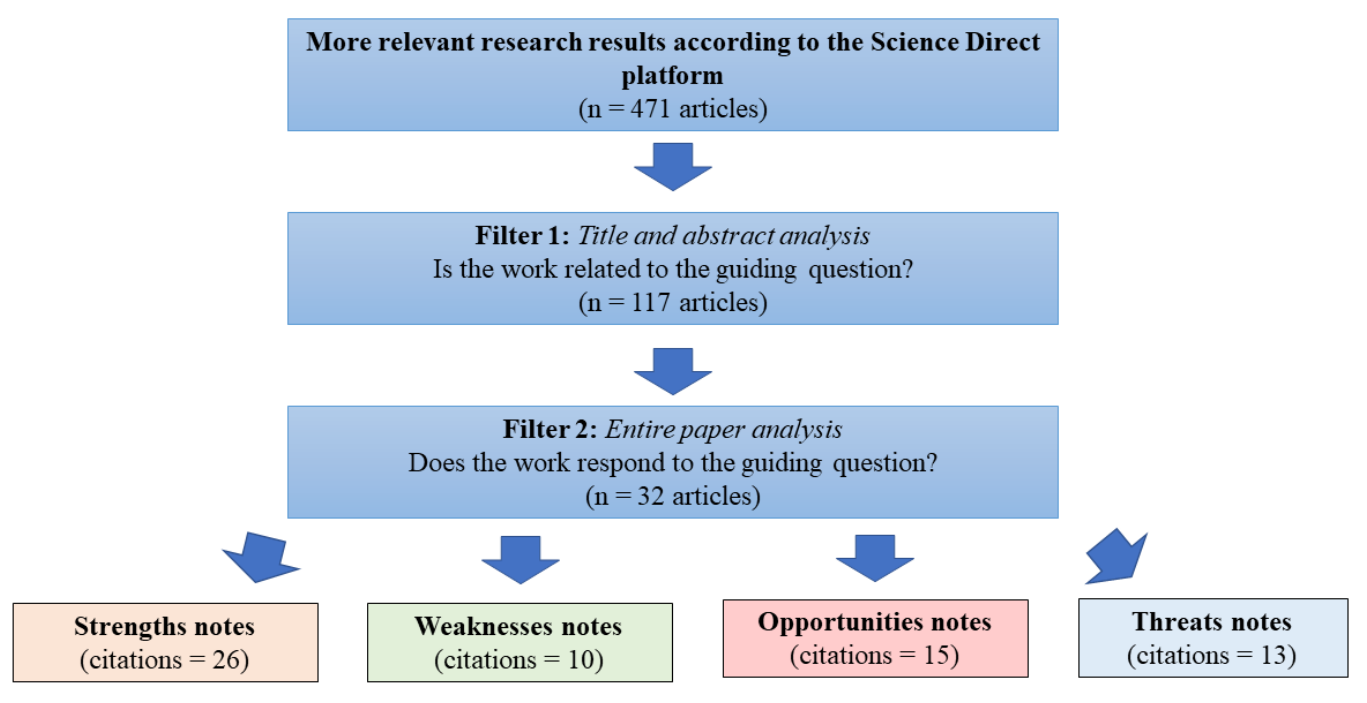

Source: Authors (2021).

\subsection{Data sources}

As mentioned above, the Science Direct platform was used as a basis for searching bibliographic data. The search initially found 471 works, using the descriptors: "shale gas" and "energy transition". Then, an advanced search was carried out, only filtering the results by title, abstract, and keywords that contained the term "energy transition," with a coverage period from 2010 to 2021, as the development of shale gas began to be widely disseminated in the second decade of the 21 st century. The advanced search found 117 results: 15 review papers, 83 original research papers, 8 book chapters, and 1 editorial. The search date was March 16, 2021. After a complete analysis of the 117 works, only 32 works were considered in the elaboration of the SWOT matrix. The other works did not bring notes on the development of shale gas linked to the energy transition. Arend et al. (2022) have prepared a study with an analysis of 41 reports of the liquefied natural gas market in Brazil through the SWOT matrix, serving as the basis for this paper.

\subsection{SWOT analysis}

In this research, to analyze the positive and negative points of shale gas in the energy transition scenario, two correlation matrices were created: (i) among opportunities and strengths and weaknesses and (ii) among threats and strengths and weaknesses. For analysis purposes, the number of citations of weaknesses and threats was considered negative, as weaknesses are internal negative aspects of shale gas development and threats are external negative aspects of it, as in any project. To create the relationship matrices, the quantities of citations at each intersection were added.

\section{Results and Discussion}

\subsection{SWOT matrix}

The SWOT matrix presents the strengths, weaknesses, opportunities, and threats of a given project, and its origins refer to the business management bibliography (Markovska et al., 2009). To prepare the SWOT matrix, the 117 works from step 1 were reviewed, and the notes referring to the application of shale gas in the energy transition were selected. Articles that did not provide notes on the contextualization of shale gas in the energy transition scenario were excluded from the database.

At the end of the notes, 32 works, 1 book chapter, and 31 papers were selected. Figure 3 shows the map of keyword interactions for the 31 selected articles (the book chapter does not have keywords and abstracts, so it is not included in the 
analysis of keywords and abstracts). As can be seen, the term "energy transition" has a great prominence, forming a cluster with "energy policy," "governance," "innovation," "renewable energy," etc. The term "shale gas" also appears with great prominence, being linked to the terms "China," "blue water," "sustainability transitions," "controversy," etc. Shale gas interacts with several energy sources, both directly (in its cluster, in purple) and indirectly (sources that are in other clusters such as "coal" or "nuclear").

The interactions with the term "energy transition" (see Figure 2) can be understood simply, despite the energy transition being a complex system change process. The energy transition is aimed at decarbonizing the energy sector and its main tools are the expansion of renewable energy and other carbon-neutral energy sources, the phasing out of fossil energy development, and the reduction of energy demand through measures that aim to increase energy efficiency (Quitzow et al., 2021).

Figure 2. Interaction map of the keywords of the selected articles.

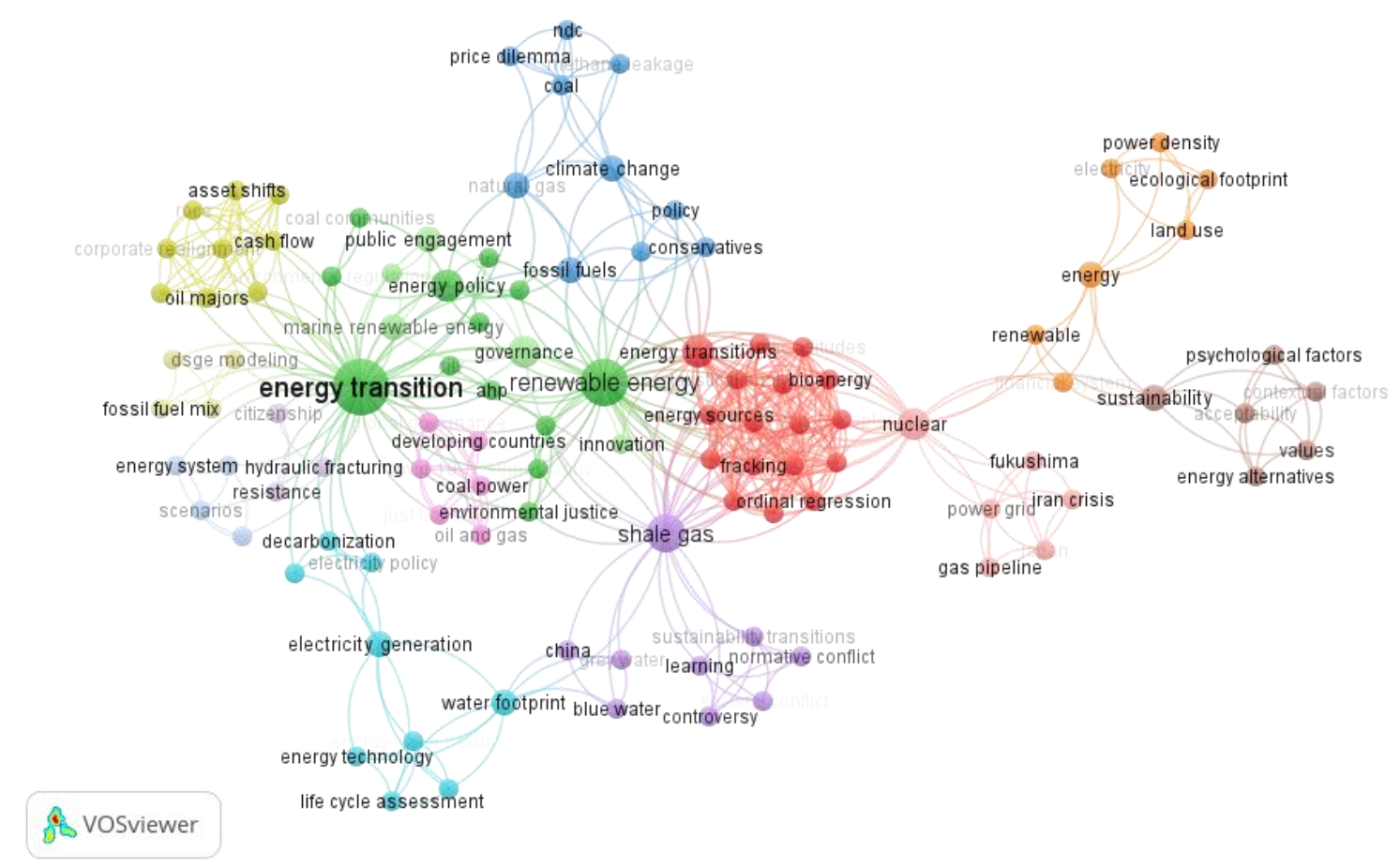

Source: Authors (2021).

After analyzing the abstracts of the selected works, it was observed that "shale gas" is linked to "fracking," "energy technology," "renewable energy technology," "electricity," etc. In the interaction map (see Figure 3), terms such as "decade," "period," “decarbonization," "progress," "government," “implementation," and "climate change" can also be noted. The term "the Netherlands" also appeared, as two papers analyzed the perspective of shale gas development in that country, correlating it with the context of energy transition (Cuppen et al., 2019; E. D. Rasch et al., 2016). 
Research, Society and Development, v. 11, n. 3, e3211326282, 2022

(CC BY 4.0) | ISSN 2525-3409 | DOI: http://dx.doi.org/10.33448/rsd-v11i3.26282

Figure 3. Interaction map of the abstracts of selected articles.

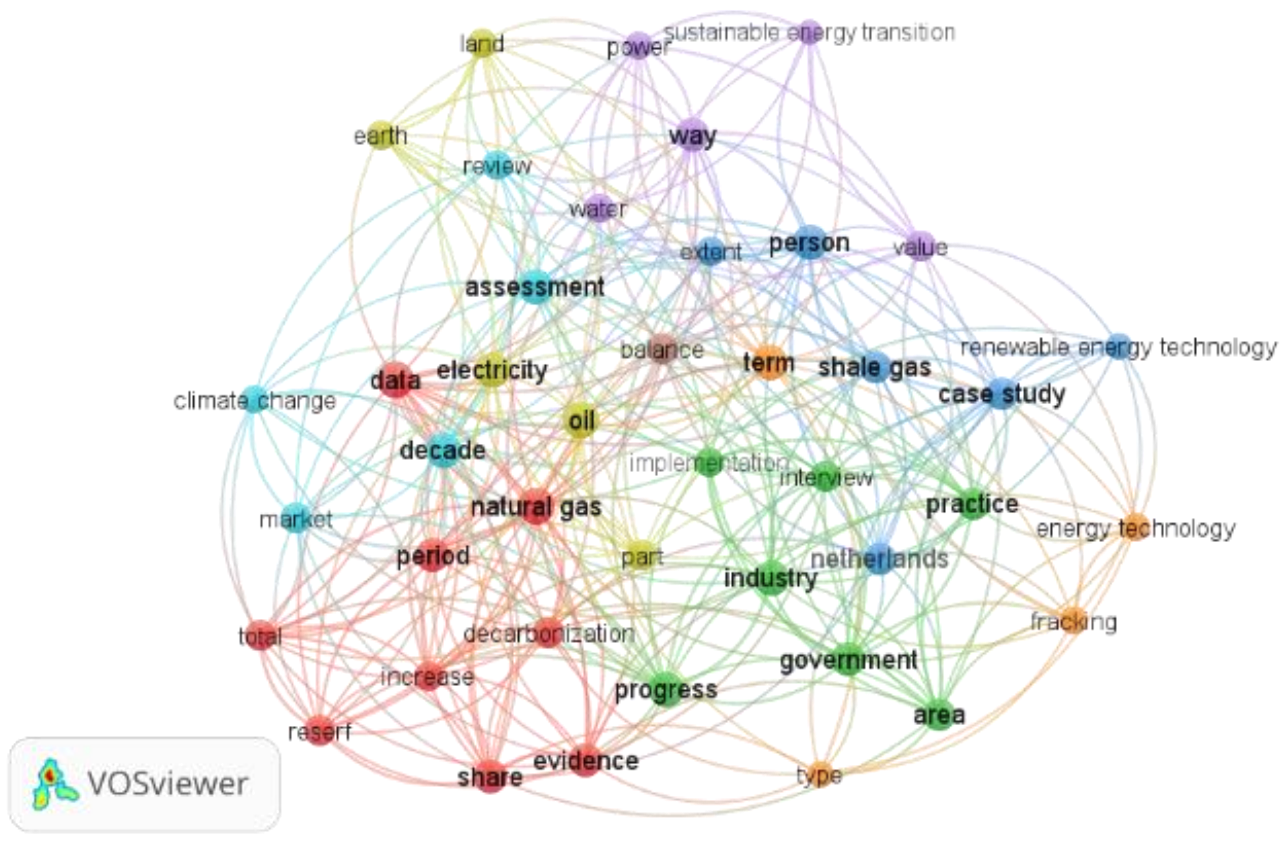

Source: Authors (2021).

Table 1 shows the SWOT matrix resulting from the bibliographic notes. There were 26 citations of strengths, 10 citations of weaknesses, 15 citations of opportunities, and 13 citations of threats.

Table 1. SWOT matrix with bibliographic notes on the use and exploration of shale gas.

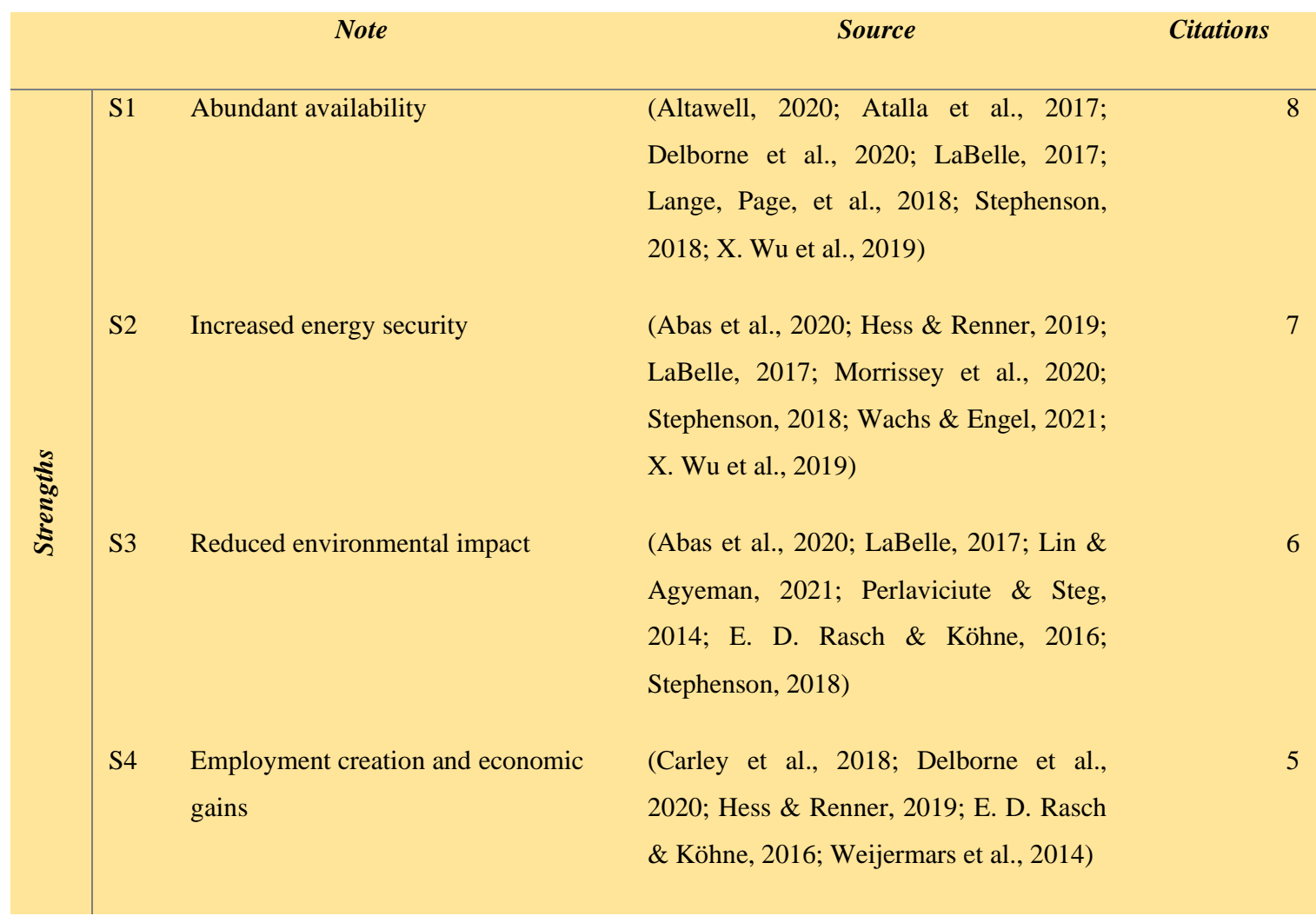




\begin{tabular}{|c|c|c|c|c|}
\hline \multirow{4}{*}{ 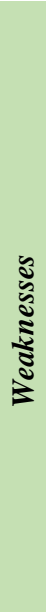 } & W1 & Environmental impacts and pollution & $\begin{array}{l}\text { (Delborne et al., 2020; Demski et al., } \\
\text { 2015; Guler et al., 2018; Stephenson, } \\
\text { 2018; Wachs \& Engel, 2021) }\end{array}$ & 5 \\
\hline & W2 & $\begin{array}{l}\text { Required use of horizontal well } \\
\text { drilling and hydraulic fracturing }\end{array}$ & (Jin et al., 2019; Stephenson, 2018) & 2 \\
\hline & W3 & $\begin{array}{l}\text { Economic barriers and investment } \\
\text { risks }\end{array}$ & (LaBelle, 2017; Weijermars et al., 2014) & 2 \\
\hline & W4 & $\begin{array}{l}\text { Possible downfall in the sustainable } \\
\text { energy market }\end{array}$ & (E. D. Rasch \& Köhne, 2016) & 1 \\
\hline \multirow{4}{*}{ 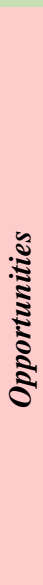 } & $\mathrm{O} 1$ & Prospects for replacing other sources & $\begin{array}{l}\text { (Carley et al., 2018; Davis et al., 2016; } \\
\text { Hess \& Renner, 2019; LaBelle, 2017; } \\
\text { Santos-Alamillos et al., 2017; Xu, 2020) }\end{array}$ & 6 \\
\hline & $\mathrm{O} 2$ & $\begin{array}{l}\text { Support of the shale gas development } \\
\text { industry and related new technologies }\end{array}$ & $\begin{array}{l}\text { (Hess and Renner, 2019; LaBelle, 2017; } \\
\text { Morrissey et al., 2020; Roddis et al., } \\
\text { 2019; Tanaka, 2013) }\end{array}$ & 5 \\
\hline & $\mathrm{O} 3$ & Prospects of international trade & $\begin{array}{l}\text { (Abas et al., 2020; Buira et al., 2021; } \\
\text { Lange, O'Hagan, et al., 2018) }\end{array}$ & 3 \\
\hline & $\mathrm{O} 4$ & Exhaustion of conventional NG fields & (E. D. D. Rasch \& Köhne, 2017) & 1 \\
\hline \multirow{4}{*}{$\frac{\xi}{\vdots}$} & $\mathrm{T} 1$ & $\begin{array}{l}\text { Public skepticism and less support } \\
\text { than that for renewable energies }\end{array}$ & $\begin{array}{l}\text { (Cuppen et al., 2019; Delborne et al., } \\
\text { 2020; Jouvet \& De Perthuis, 2013; E. D. } \\
\text { Rasch \& Köhne, 2016; Roddis et al., } \\
\text { 2019) }\end{array}$ & 5 \\
\hline & $\mathrm{T} 2$ & Ban & $\begin{array}{l}\text { (Hess \& Renner, 2019; LaBelle, 2017; } \\
\text { Quitzow et al., 2021) }\end{array}$ & 3 \\
\hline & $\mathrm{T} 3$ & Politicization & $\begin{array}{l}\text { (Delborne et al., 2020; Hess \& Renner, } \\
\text { 2019; E. D. Rasch \& Köhne, 2016) }\end{array}$ & 3 \\
\hline & $\mathrm{T} 4$ & $\begin{array}{l}\text { Restrictions (such as deeper shale } \\
\text { resources and insufficient water } \\
\text { availability) }\end{array}$ & (Qin et al., 2018; Z. Wang et al., 2017) & 1 \\
\hline
\end{tabular}

Source: Authors (2021).

Through Table 1, the main strength has found, for shale gas development, has been abundant availability (8 citations) followed by increased energy security ( 7 citations). The biggest opportunity has been prospects for replacing other sources (6 citations) followed by support of the shale gas development industry and related new technologies (5 citations). The biggest weakness has been environmental impacts and pollution (5 citations) and the biggest threat the public skepticism and less support than that for renewable energies (5 citations). In Table 1, what should be observed is which are the notes have found in 
the preparation of the SWOT matrix.

Figure 4 shows the word cloud with notes from the SWOT matrix. You can notice that the words "prospects," "energy," "shale," and "gas" gained great prominence. It can be noted that in the development of shale gas terms such as energy, environment, sustainability, skepticism, politicization, and employments have significant prominence. Thus, what is important to note in Figure 4 are which terms are most present in the articles studied.

Figure 4. SWOT matrix notes word cloud.

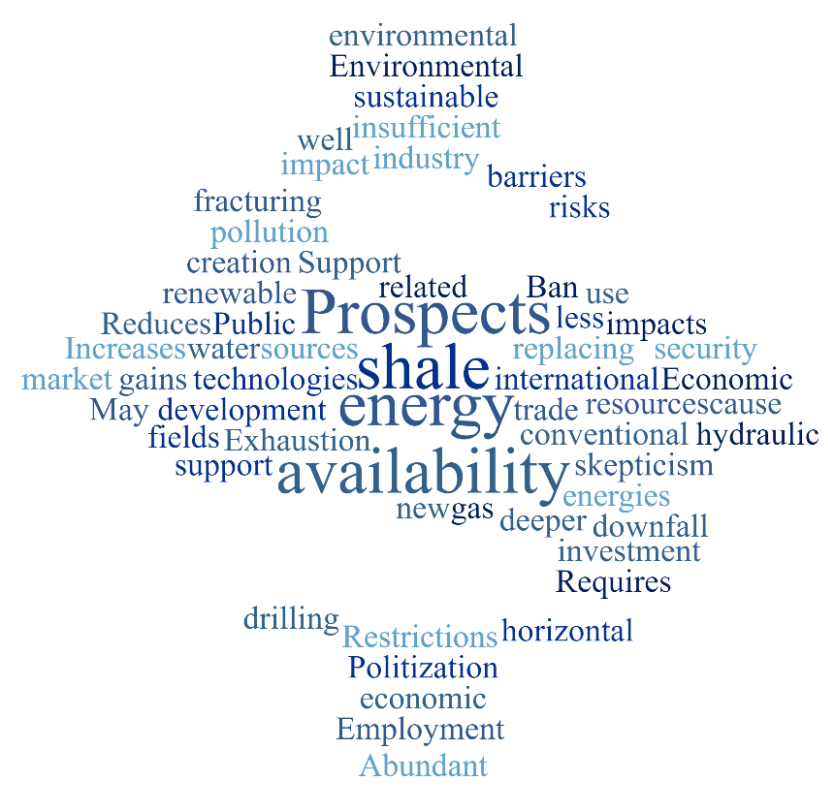

Source: Authors (2021).

\subsubsection{Strengths}

One of shale gas's greatest strengths is its abundance, as detailed in Section 2 of this paper. There is a large volume of reserves in the US, China, countries in Latin America (mainly Argentina and Mexico), Africa (particularly Algeria and South Africa), Russia, and Australia (Agency, 2011; Euzen, 2011). The vast abundance of shale gas could spur a new global gas market in the coming years (IEA, 2019), as well as an increase in NG consumption in the US and other countries (Atalla et al., 2017; EIA, 2016), and the replacement of other sources that cause greater environmental impacts (Altawell, 2020; X. Wu et al., 2019).

As for the energy security strength, it is noteworthy that due to the growth in the development of shale gas, the US is no longer dependent on imported oil from the Middle East (Abas et al., 2020), that is, the development of shale gas can contribute to less dependence on foreign oil products (Hess et al., 2019). Still, in the context of international trade, it should be mentioned that due to the low price of American NG, as a result of the increased exploitation of shale gas, the countries of the European Union may become less dependent on Russian NG (Kim et al., 2015). Shale gas can offer a relatively cleaner energy transition (LaBelle, 2017; X. Wu et al., 2019), it can also provide a level of energy security similar to a matrix predominantly based on the use of coal (LaBelle, 2017), and it can be a tool to provide energy security while renewable energies are not consolidated (Dutu, 2016), since renewable energies face problems of intermittence and lack of energy density. In this way, shale gas could guarantee energy security while renewable energies are not consolidated in the global energy matrix (Howarth, Ingraffea, et al., 2011; Kerr, 2010).

In addition to ensuring an increase in energy security, shale gas can provide a reduction in carbon emissions (Abas et 
al., 2020). Shale gas development could contain rising GHG emissions (Lin et al., 2021). Among fossil sources, NG, and consequently shale gas, is seen as a source with relatively lower emissions (Perlaviciute et al., 2014). The reduction of GHG emissions is defended by the shale industry as one of the advantages of the consumption of shale gas, even in opposition to the use of coal, thus replacing the consumption of coal with NG (Stephenson, 2018). There is evidence that carbon dioxide $\left(\mathrm{CO}_{2}\right)$ emissions can be significantly reduced by substituting coal with the use of NG (Lin et al., 2021).

The employment creation strength can be used to take advantage of shale gas development opportunities as well. Barnett Shale, in the US, employed approximately 100,000 people in 2011 (House, 2013; Sovacool, 2014). Despite these positive data, there are uncertainties regarding the evolution of the number of unemployed and the increase in income in the same location (The Academy of Medicine Engineering and Science of Texas, 2017). Marcellus Shale, located in West Virginia and Pennsylvania (US), created about 57,000 new jobs in 2009 (Scott, 2013; Sovacool, 2014). In the UK, shale gas development is expected to generate between 32,000 and 74,000 direct, indirect, and induced jobs (Cooper et al., 2018). In the Chinese context, the development of shale gas would allow social benefits that include: increased employment, increased tax revenue, and indirect reduction of losses from mine accidents (by replacing coal mining with shale gas exploration) (J. Liu et al., 2020).

\subsubsection{Weaknesses}

Despite being considered an energy source with lower impacts when compared to other fossil sources, shale gas can represent a continuation of fossil fuel consumption, which is associated with negative impacts on the environment and human health (as mentioned in the introduction of this paper) (Demski et al., 2015). The combustion of shale gas emits fewer amounts of $\mathrm{CO}_{2}$ than the combustion of coal. However, the production of the resource emits more $\mathrm{CH} 4$ than conventional NG production (J. Wang et al., 2011). In a Life Cycle Analysis (LCA), the emissions of CH4 from shale gas production, over a 20year horizon, could be greater than emissions from conventional NG, coal, and diesel oil. Over a 100-year horizon, there is a change in trend and shale gas becomes less impactful on global warming than coal and diesel oil (Delborne et al., 2020; Howarth, Santoro, et al., 2011; Stephenson, 2018).

In addition to the possible impacts on global warming, shale extraction can cause high impacts on temperate forests and pastures (Wachs \& Engel, 2021) and possibly on boreal forests. In BC, most shale gas extraction activities are taking place in the province's boreal forest. However, forest change in the region may not be related to shale exploration (Oduro Appiah et al., 2020). BC's boreal zone covers 32 million hectares and forms an essential part of the province's diverse and complex network of ecosystems. The demand for shale resources can contribute to more changes in the environment. However, these externalities can be mitigated (Oduro Appiah et al., 2020).

One of the great weaknesses of shale gas is the essential use of fracking. Horizontal well drilling was developed in the 1940s in the Soviet Union and was followed in 1949 by fracking in Stephens County, Oklahoma, and Archer County, Texas. Horizontal drilling with fracking became the essential tools for the growth of shale gas development in the early 2000 s in Texas (Stephenson, 2018). Despite being essential to the development of shale gas, fracking has several impacts on the environment and human health (Jin et al., 2019), as mentioned earlier in this paper. Environmental impacts can be even greater, depending on the region. For example, China's more complicated shale formations and water-intensive fracking techniques resulted in higher water consumption than in the US (Jin et al., 2019).

Another weakness found in shale gas development is the financial risk involved in the projects. In Poland, by 2015 , more than $\$ 2$ billion had been invested in shale exploration, and despite this, no well was still consistently in production (LaBelle, 2017). It is noteworthy that in the country, companies started to abandon fracking in 2013 due to geological 
conditions (Cantoni et al., 2018). Even in the US, where the so-called "shale gas revolution" took place, some companies had problems generating cash flow from operations due to low NG prices on the regional market (Weijermars et al., 2014). Uncertainties are high for shale development, societal acceptance may be low, and major technology improvements are needed to make these field projects profitable (Weijermars et al., 2014).

Shale gas can delay an effective transition to a low carbon matrix, as it is a fossil and non-renewable source. It can even be considered opposed to a sustainable matrix and may even be considered a retarder and not an accelerator of the energy transition to low carbon (Demski et al., 2015; Hess et al., 2019; E. D. Rasch et al., 2016). Referring to the Jevons paradox, in which technological improvement can lead to an increase in demand (Giampietro et al., 2018), the technological improvement in the development of shale gas can cause an increase in NG, removing the need for energy savings and also may bring about its downfall on the sustainable energy market (E. D. Rasch et al., 2016).

\subsubsection{Opportunities}

The main opportunity for the development of shale gas is the replacement of other fossil sources, especially coal. Since the beginning of the 21 st century, the coal industry has been losing ground due to advanced mechanization, decreased mining productivity, and environmental regulations. Compounding the loss of space, the prices of coal substitutes such as NG, wind, and solar power have fallen, thus making the decline of the coal industry intense (Carley et al., 2018). From 2011 to 2020, more than 100 coal-fired power plants were switched to NG in the US. American coal-fired power generation continues to grapple with the challenges of NG emission standards and low prices. Thus, it is expected that more conversions of coalfired power plants to NG will take place in the future (EIA, 2020).

Another opportunity for the development of shale gas is the support that it may gain, either by society or by governments. In 2013, in Poland, former Prime Minister Donald Tusk supported the development of shale gas in Polish territory. At the height of the shale gas project in the country, $82 \%$ of the society supported the opinion that the exploration of shale gas should be prioritized in relation to other fossil fuels (LaBelle, 2017). In the US, the start of shale gas development was supported by then-President Barack Obama (Varela, 2020). With the support of the government, the development of shale gas in the country brought about the "shale gas revolution", also called "the golden age of gas" (Tanaka, 2013).

Liquefied shale gas can be transported over great distances. This favors the opportunity to expand the global liquefied gas market (Abas et al., 2020), as mentioned in the introduction of this paper. In Mexico, the use of NG is widespread and growing due to low-cost US shale gas imports (Buira et al., 2021). In the Republic of Ireland, domestic oil competes with shale gas imported from other regions (Lange, O’Hagan, et al., 2018). In this way, it is possible to notice that shale gas has a huge perspective in international trade, being able to be easily exported in liquefied form and taking advantage of the opportunity of trade between countries.

In the Netherlands, until 2014, the conventional gas fields in Groningen were close to depletion (E. D. D. Rasch \& Köhne, 2017), and just like what happened in that country, other wells will likely run dry all over the planet. However, the worldwide consumption of fossil energy grows year by year, and it is estimated that there are still many reserves to be burned (Ritchie, 2017). Since Groningen has suffered numerous earthquakes, the near depletion of conventional gas fields in the region, and a change in the international political economy of gas, two Dutch ministers of the economic sector have been led to present shale gas as a transitional fuel (E. D. D. Rasch \& Köhne, 2017). In this way, shale gas development can take advantage of the opportunity of the depletion of conventional NG fields to increase its production, as well as the other factors mentioned above. 


\subsubsection{Threats}

One of the main threats to shale gas development is public skepticism or less support than that for renewable energy. Some of the public and academics do not believe that shale gas is a bridge to a transition to low carbon or that is emits less than other fossil sources (Cuppen et al., 2019; Howarth, 2014). The threat of skepticism may be compounded by the environmental impacts caused by shale gas exploration. Despite its high emission values of $\mathrm{CH} 4$, this scenario can be reversed with regulation, driving industries in the sector to reduce the same (Howarth et al., 2011). Even with these considerations, scientist Robert W. Howarth still considered shale gas a bridge to nowhere due to its high environmental impacts (Guler et al., 2018; Howarth, 2014).

Another threat to the development of shale gas found is the risk of banishment. In this context, in 2011, French society mobilized, and the exploitation of shale gas was banned in the country. The ban on shale gas exploration in France did not end social mobilization on fossil fuel production, and, in 2017, a bill was presented to parliament to ban all hydrocarbon exploration by the end of 2040 (Chailleux et al., 2018). The French parliament has enacted the law, and no new licenses will be granted to extract fossil fuels, and no existing licenses will be renewed after 2040 (The Guardian, 2017). So far, 5 countries in Europe have banned fracking: France, Bulgaria, Germany (with some exceptions), Spain (with some limitations, too), and the Republic of Ireland, which banned fracking in its territory in 2017 (Burdis, 2021). Denmark, the Netherlands, Northern Ireland, Scotland, and Wales declared a moratorium on fracking exploitation. In Latin America, Uruguay banned fracking for 4 years (since 2017). In Argentina, the Province of Entre Rios banned the use of fracking in 2017, and Costa Rica declared a moratorium on it (Herrera, 2020; Hess et al., 2019; LaBelle, 2017).

Politicization is also a threat to shale gas development that shale gas weaknesses can exacerbate. The theme was one of the key issues in the US debate, in 2020, between presidential candidate Donald Trump and his opposition Joe Biden. Although President Joe Biden said he would not ban fracking if he were elected, the Republican Vice President, Mike Pence, accused him of bantering the process (Goswami et al., 2020). During Trump's administration, the oil and gas sector benefited from fiscal and regulatory measures, such as the massive purchase of corporate bonds by the Federal Reserve, reduction of royalties and rent payments by the Federal Bureau of Land Management, in addition to the granting of licenses and relaxation of environmental regulations (Guliyev, 2020). With Biden's election victory in November 2020, this trend could be reversed. The current president has temporarily suspended all drilling rights licenses, revoked the license for the controversial Keystone pipeline, and plans to impose a moratorium on oil drilling on federal lands (Guliyev, 2020). It is worth noting that Biden, when Barack Obama's vice president, supported his administration at the time when the exploitation of shale gas through fracking began (Varela, 2020).

Shale gas development may also face threats from the projects' physical constraints. Shale gas exploration encountered different barriers in China compared to American exploration, including geological constraints (deeper shale resources), insufficient water availability, and, consequently, increased costs. The market barrier can also be mentioned since the exploration of shale resources in China was controlled by three companies in the oil and gas sector, resulting in an uncompetitive market (Qin et al., 2018). So far, globally, shale gas reserves with fewer complexities have been explored, but when more complex reserves start to be explored, threats tend to increase, as well as project costs (Z. Wang et al., 2017).

\subsection{Opportunities to be explored in shale gas development}

Table 2 shows the correlation between the number of citations of opportunities with the strengths and weaknesses of shale gas development linked to the energy transition. In stronger colors are the correlations that showed the highest results. It can be noticed that the quadrant between opportunities and strengths was mentioned more than the quadrant between 
opportunities and weaknesses. It can be analyzed that, in the context of the energy transition, what most draws the researchers' attention are the positive aspects of the development of shale gas. However, the weaknesses of shale gas exploitation should not be overlooked.

According to the analysis in Table 2, a possible path for the development of shale gas is to take advantage of opportunities to replace other more polluting fossil sources and support the development of shale gas to use its abundance and energy security strengths. It can be mentioned that the shale gas industry in the US has become a consolidated industry due in large part to government support. However, in other countries, it is still a disruptive industry despite the resource's energy abundance. In the context of disruptive industry, shale gas development is subject to economic, physical, political, and technical uncertainties that may be related to its weaknesses and threats (Aguilera et al., 2012; Melikoglu, 2014). Thus, for a promising path to be followed, it will be necessary to address the weaknesses of shale development. Despite being less mentioned than the strengths, the weaknesses exist and need to be mitigated.

Table. 2. Matrix of positive points of shale gas development.

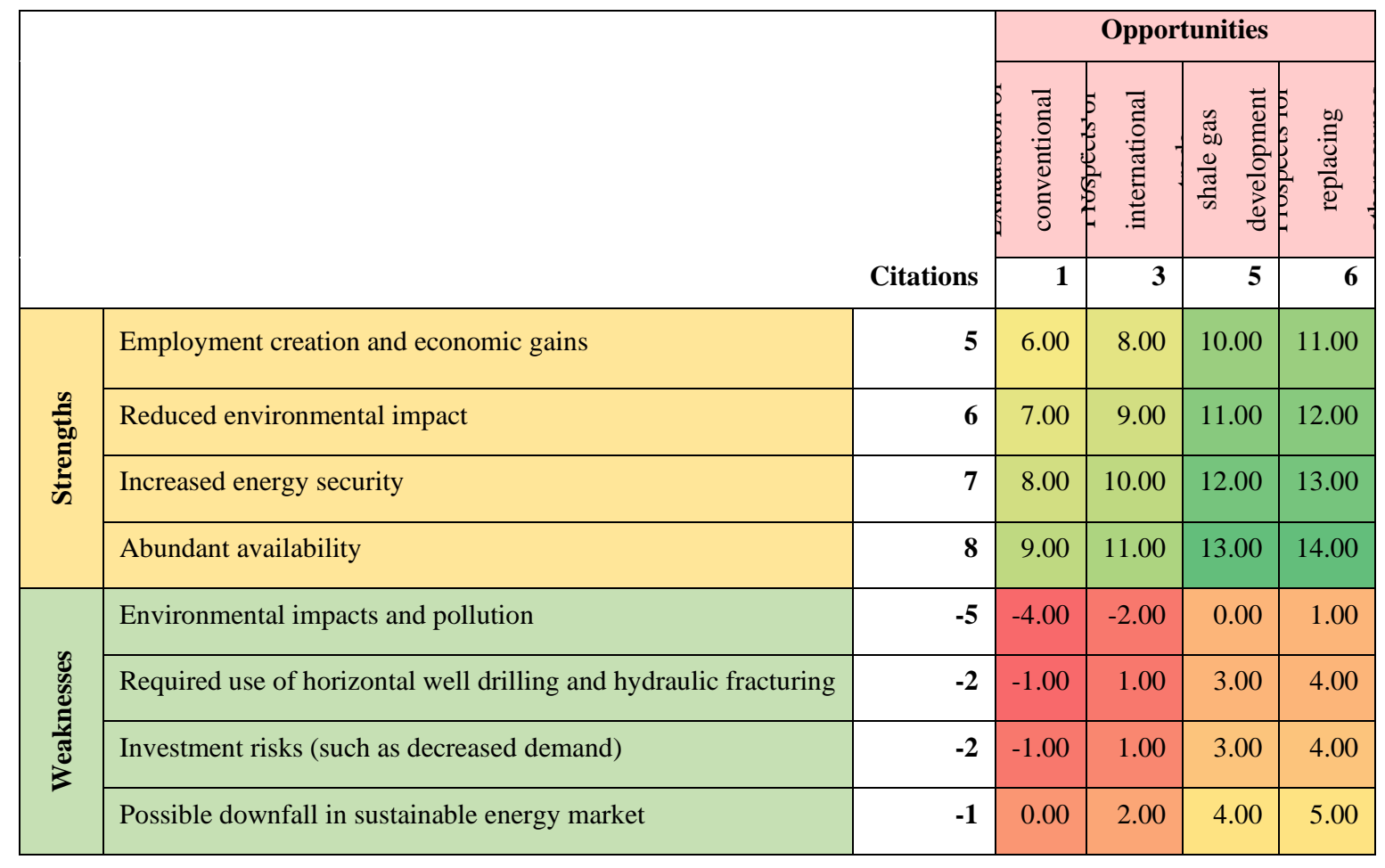

Source: Authors (2021).

\subsection{Challenges to be overcome in shale gas development}

Table 3 shows the correlation between the number of citations of threats and the strengths and weaknesses of shale gas development linked to the energy transition. In stronger colors are the correlations that showed the highest results. In this analysis, it can be noted that the factors that most concerned researchers were public skepticism and the environmental impacts caused by the exploration of shale gas. The combination of threats and weaknesses in shale gas development could negatively leverage the exploitation of shale gas as an energy transition tool. However, the threat citations were quantitatively outnumbered by the strength citations from the shale gas development. 
Table. 3. Matrix of negative points of shale gas development

\begin{tabular}{|c|c|c|c|c|c|c|}
\hline & & & & & eats & \\
\hline & & & 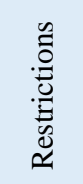 & 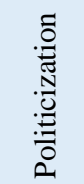 & $\underset{\text { صే }}{\text { صే }}$ & 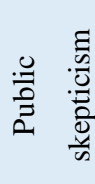 \\
\hline & & Citations & -2 & -3 & -3 & -5 \\
\hline & Employment creation and economic gains & 5 & 3.00 & 2.00 & 2.00 & 0.00 \\
\hline$\stackrel{n}{D}$ & Reduced environmental impact & 6 & 4.00 & 3.00 & 3.00 & 1.00 \\
\hline 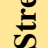 & Increased energy security & 7 & 5.00 & 4.00 & 4.00 & 2.00 \\
\hline & Abundant availability & 8 & 6.00 & 5.00 & 5.00 & 3.00 \\
\hline & Environmental impacts and pollution & -5 & -7.00 & -8.00 & -8.00 & -10.00 \\
\hline 帝 & Required use of horizontal well drilling and hydraulic fracturing & -2 & -4.00 & -5.00 & -5.00 & -7.00 \\
\hline 㐘 & Investment risks (such as decreased demand) & -2 & -4.00 & -5.00 & -5.00 & -7.00 \\
\hline & Possible downfall in sustainable energy market & -1 & -3.00 & -4.00 & -4.00 & -6.00 \\
\hline
\end{tabular}

Source: Authors (2021).

The threats and weaknesses of shale gas development can be minimized by implementing regulatory policies. In this way, shale gas can become a relatively clean and economical transition fuel if some measures are taken, such as reduction of the methane leakage rate by $90 \%$; circularity of the water used in the fracking process, or underground injection if the same cannot be reused (Jenner et al., 2013); replacement of pneumatic devices and compressor seals; and reduced ventilation (K. Wu et al., 2016). A possible alternative to internalizing the negative externalities (environmental impacts) of shale gas development would be the carbon tax; however, due to potential public opposition to the increase in taxes, the most tangible path would be regulation (Jenner et al., 2013).

If fugitive emissions from $\mathrm{CH} 4$ are treated, shale gas can become a relatively clean fuel and can be used together with renewable energies (Carbon Brief Staff, 2012). Shale formations may also store $\mathrm{CO}_{2}$ captured through the implementation of Carbon Capture and Storage (CCS). However, studies on the subject are still incipient, and countries such as China and those within the MENA region are still having difficulties with exploiting shale gas (Khosrokhavar et al., 2014). Finally, shale gas can become a bridge to a cleaner, carbon-free energy transition. A study published in 2016 showed that shale gas production could provide enough energy to build a renewable energy system consisting of wind and photovoltaic energy. That same system could supply $83 \%$ of electricity demand in 15 years (K. Wu et al., 2016).

\section{Conclusion}

The biggest change in the oil and gas industry in recent years has been the proliferation of fracking. Fracking made shale gas an economically viable option, thus increasing NG production, mainly in the US. However, the exploration of shale gas can significantly impact the environment, such as water contamination and increased GHG emissions in a holistic aspect. Despite its negative impacts, shale gas can be used as a bridge to a low-carbon energy transition, although this aspect is controversial. 
In the works selected for the review of this paper, the term shale gas was related to sustainability transitions and controversy, thus showing the controversy of its use. The term energy transition was related to energy policy, governance, innovation, and renewable energy. The relationship of these terms can show that the energy transition must occur with energy policies, governance, innovation, and renewable energy. Renewable energies can mitigate GHG emissions, but they cannot guarantee global energy security by themselves. Opportunities to replace other more polluting sources, essentially coal, and support the development of the shale gas industry can benefit countries with increased energy security and job creation. However, for this process to occur, it will be necessary to internalize the environmental externalities of shale gas exploration.

Thus, the exploration of shale gas can be indicated when there is efficient regulation. Regulations could cause a reduction in $\mathrm{CH} 4$ emissions and in nearby water contamination as well. Companies that seek constant improvements would benefit, reduce their emissions and environmental impacts, and explore the energy source. Carbon taxation is also another good way to develop shale gas. In any case, the exploration of shale gas should only be done with the consent of civil society and as mentioned above, with the internalization of externalities.

Future research with reverent studies on the replacement of coal by shale gas is suggested, since one of the main opportunities for the development of shale gas is the decarbonization of the energy matrix, mainly with the replacement of coal. It may become important to study how much the GHG emissions can be reduced, in the present and in the future, by replacing coal-fired plants with plants of NG extracted from shale. How shale gas could provide energy security to matrices in different countries can also be studied, since one of the greatest strengths of shale gas is the increase in energy security, just like NG.

\section{Acknowledgments}

Cachola thanks the current support by CNPq [grant number 380184/2021-4]. Afonso thanks the current support by CNPq [grant number 180366/2021-1]. Cachola, Peyerl and Moutinho dos Santos gratefully acknowledge support from SHELL Brazil and FAPESP through the Research Centre for Gas Innovation (RCGI) (FAPESP Proc. 2014/50279-4 e 2020/15230-5), hosted by the University of São Paulo, and the strategic importance of the support given by ANP through the Research \& Development levy regulation. Peyerl thanks especially the current financial support of grant Process 2017/18208-8 e 2018/26388-9, São Paulo Research Foundation (FAPESP).

\section{References}

Abas, N., Kalair, E., Kalair, A., Hasan, Q. ul, \& Khan, N. (2020). Nature inspired artificial photosynthesis technologies for hydrogen production: Barriers and challenges. International Journal of Hydrogen Energy, 45(41), 20787-20799. https://doi.org/10.1016/j.ijhydene.2019.12.010

Absar, S. M., Boulay, A. M., Campa, M. F., Preston, B. L., \& Taylor, A. (2018). The tradeoff between water and carbon footprints of Barnett Shale gas. Journal of Cleaner Production, 197, 47-56. https://doi.org/10.1016/j.jclepro.2018.06.140

Aczel, M. R., Makuch, K. E., \& Chibane, M. (2018). How much is enough? Approaches to public participation in shale gas regulation across England, France, and Algeria. Extractive Industries and Society, 5(4), 427-440. https://doi.org/10.1016/j.exis.2018.10.003

Agency, I. E. (2011). Are We Entering A Golden Age of Gas? World Energy Outlook, November, 329. http://www.iea.org/weo/docs/weo2011/WEO2011_GoldenAgeofGasReport.pdf

Aguilera, R. F., \& Aguilera, R. (2012). World natural gas endowment as a bridge towards zero carbon emissions. Technological Forecasting and Social Change, 79(3), 579-586. https://doi.org/10.1016/j.techfore.2011.09.004

Alberto, J., \& Ibarzábal, H. (2018). The Extractive Industries and Society Can shale gas development in Mexico be smart regulated ? A qualitative analysis of the regulatory setting, challenges and perspectives. The Extractive Industries and Society, 5(4), 490-498. https://doi.org/10.1016/j.exis.2018.08.008

Altawell, N. (2020). Coal. In Rural Electrification: Optimizing Economics, Planning and Policy in an Era of Climate Change and Energy Transition (pp. 1938). https://doi.org/10.1016/B978-0-12-822403-8.00002-3

Amec Foster Wheeler. (2015). Shale Gas Study. April, 276. http://www.anp.gov.br/SITE/acao/download/?id=82613 
Andreasson, S. (2018). The bubble that got away? Prospects for shale gas development in South Africa. Extractive Industries and Society, 5(4), 453-460. https://doi.org/10.1016/j.exis.2018.07.004

Arend, L., Silva, Y. F. M. da, Pereira, C. A. A., Santos, E. M. dos, \& Peyerl, D. (2022). Prospects and challenges of the liquefied natural gas market in Brazil. Research, Society and Development, 11(2), e11811225527. https://doi.org/10.33448/rsd-v11i2.25527

Atalla, T., Blazquez, J., Hunt, L. C., \& Manzano, B. (2017). Prices versus policy: An analysis of the drivers of the primary fossil fuel mix. Energy Policy, 106(October 2016), 536-546. https://doi.org/10.1016/j.enpol.2017.03.060

Atkinson, D. (2018). Fracking in a fractured environment: Shale gas mining and institutional dynamics in South Africa's young democracy. Extractive Industries and Society, 5(4), 441-452. https://doi.org/10.1016/j.exis.2018.09.013

Azubuike, S. I., Songi, O., Irowarisima, M., \& Chinda, J. K. (2018). Identifying policy and legal issues for shale gas development in Algeria: A SWOT analysis. The Extractive Industries and Society, 5(4), 469-480. https://doi.org/10.1016/j.exis.2018.10.005

Becker, V., \& Werner, A. (2014). One Step Forward, One Step Back: Shale Gas in Denmark and Sweden. Journal of European Management \& Public Affairs Studies, 1(2), 23-30. https://doi.org/10.15771/2199-1618_2014_1_2_4

Bellani, J., Verma, H. K., Khatri, D., Makwana, D., \& Shah, M. (2021). Shale gas: a step toward sustainable energy future. Journal of Petroleum Exploration and Production, 0123456789. https://doi.org/10.1007/s13202-021-01157-7

Boersma, T., Leber, A., \& Potvin, J. (2015). Shale Gas in Algeria. November.

Bouman, E. A., Ramirez, A., \& Hertwich, E. G. (2015). Multiregional environmental comparison of fossil fuel power generation-Assessment of the contribution of fugitive emissions from conventional and unconventional fossil resources. International Journal of Greenhouse Gas Control, 33, 1-9. https://doi.org/10.1016/j.ijggc.2014.11.015

Buira, D., Tovilla, J., Farbes, J., Jones, R., Haley, B., \& Gastelum, D. (2021). A whole-economy Deep Decarbonization Pathway for Mexico. Energy Strategy Reviews, 33(October 2020), 100578. https://doi.org/10.1016/j.esr.2020.100578

Burdis, S. (2021). Calls grow for an Irish-led global ban on fracking. Green News.Ie. https://greennews.ie/ichr-report-global-ban-on-fracked-gas/

Camargo, T. R. M. de, Merschmann, P. R. de C., Arroyo, E. V., \& Szklo, A. (2014). Major challenges for developing unconventional gas in Brazil - Will water resources impede the development of the Country's industry? Resources Policy, 41(1), 60-71. https://doi.org/10.1016/j.resourpol.2014.03.001

Campbell, K., \& Horne, M. (2011). Shale Gas in British Columbia (Issue September).

Cantoni, R., Klaes, M. S., Lackerbauer, S. I., Foltyn, C., \& Keller, R. (2018). The Extractive Industries and Society Shale tales : Politics of knowledge and promises in Europe's s shale gas discourses. The Extractive Industries and Society, 5(4), 535-546. https://doi.org/10.1016/j.exis.2018.09.004

Carbon Brief Staff. (2012). Shale gas needs CCS and emissions guarantee, says Environment Agency boss. https://www.carbonbrief.org/shale-gas-needs-ccsand-emissions-guarantee-says-environment-agency-boss

Carley, S., Evans, T. P., \& Konisky, D. M. (2018). Adaptation, culture, and the energy transition in American coal country. Energy Research and Social Science, 37(October 2017), 133-139. https://doi.org/10.1016/j.erss.2017.10.007

Chailleux, S., Merlin, J., \& Gunzburger, Y. (2018). Unconventional oil and gas in France: From popular distrust to politicization of the underground. Extractive Industries and Society, 5(4), 682-690. https://doi.org/10.1016/j.exis.2018.05.007

Chang, Y., Huang, R., Ries, R. J., \& Masanet, E. (2014). Shale-to-well energy use and air pollutant emissions of shale gas production in China. Applied Energy, 125, 147-157. https://doi.org/10.1016/j.apenergy.2014.03.039

Chávez-Rodríguez, M. F., Dias, L., Simoes, S., Seixas, J., Hawkes, A., Szklo, A., \& Lucena, A. F. P. (2017). Modelling the natural gas dynamics in the Southern Cone of Latin America. Applied Energy, 201, 219-239. https://doi.org/10.1016/j.apenergy.2017.05.061

Chen, Y., Li, J., Lu, H., \& Xia, J. (2020). Tradeoffs in water and carbon footprints of shale gas, natural gas, and coal in China. Fuel, 263(September 2019), 116778. https://doi.org/10.1016/j.fuel.2019.116778

Cooper, J., Stamford, L., \& Azapagic, A. (2018). Social sustainability assessment of shale gas in the UK. Sustainable Production and Consumption, 14(December), 1-20. https://doi.org/10.1016/j.spc.2017.12.004

Costie, D. P., Holm, F., \& Berardo, R. (2021). The Extractive Industries and Society Hydraulic fracturing , coalition activity and shock: Assessing the potential for coalition-based collective action in Argentina's Vaca Muerta formation. The Extractive Industries and Society, 5(4), 499-507. https://doi.org/10.1016/j.exis.2018.08.003

Cuppen, E., Pesch, U., Remmerswaal, S., \& Taanman, M. (2019). Normative diversity, conflict and transition: Shale gas in the Netherlands. Technological Forecasting and Social Change, 145, 165-175. https://doi.org/10.1016/j.techfore.2016.11.004

Danish Energy Agency. (2021). Shale gas. https://ens.dk/en/our-responsibilities/oil-gas/shale-gas

Davis, C., Bollinger, L. A., \& Dijkema, G. P. J. (2016). The state of the states: Data-driven analysis of the US Clean Power Plan. Renewable and Sustainable Energy Reviews, 60, 631-652. https://doi.org/10.1016/j.rser.2016.01.097

Delborne, J. A., Hasala, D., Wigner, A., \& Kinchy, A. (2020). Dueling metaphors, fueling futures: "Bridge fuel" visions of coal and natural gas in the United States. Energy Research and Social Science, 61(July 2019), 101350. https://doi.org/10.1016/j.erss.2019.101350 
Demski, C., Butler, C., Parkhill, K. A., Spence, A., \& Pidgeon, N. F. (2015). Public values for energy system change. Global Environmental Change, 34, 5969. https://doi.org/10.1016/j.gloenvcha.2015.06.014

Dincer, I., \& Zamfirescu, C. (2016). A review of novel energy options for clean rail applications. Journal of Natural Gas Science and Engineering, 28, 461478. https://doi.org/10.1016/j.jngse.2015.12.007

Dutu, R. (2016). Challenges and policies in Indonesia’s energy sector. Energy Policy, 98, 513-519. https://doi.org/10.1016/j.enpol.2016.09.009

EIA. (2013). Technically Recoverable Shale Oil and Shale Gas Resources : An Assessment of 137 Shale Formations in 41 Countries Outside the United States. 2013(June).

EIA. (2016). Shale gas production drives world natural gas production growth. https://www.eia.gov/todayinenergy/detail.php?id=27512

EIA. (2020). More than 100 coal-fired plants have been replaced or converted to natural gas since 2011 https://www.eia.gov/todayinenergy/detail.php?id=44636

Eurostat. (2020). EU imports of energy products - recent developments. https://ec.europa.eu/eurostat/statisticsexplained/index.php?title=EU_imports_of_energy_products_-_recent_developments

Euzen, T. (2011). Shale gas - an overview. Corporate Document, 403, 76pp.

Evensen, D. (2018). Review of shale gas social science in the United Kingdom, 2013-2018. Extractive Industries and Society, 5(4), 691-698. https://doi.org/10.1016/j.exis.2018.09.005

Ganguli, S. (2016). Energy interdependence as a strategic factor in the post-cold war context. Strategic Analysis, 40(3), 185-198. https://doi.org/10.1080/09700161.2016.1165468

Gao, J., \& You, F. (2017). Design and optimization of shale gas energy systems: Overview, research challenges, and future directions. Computers and Chemical Engineering, 106, 699-718. https://doi.org/10.1016/j.compchemeng.2017.01.032

Giampietro, M., \& Mayumi, K. (2018). Unraveling the Complexity of the Jevons Paradox: The Link Between Innovation, Efficiency, and Sustainability. https://doi.org/https://doi.org/10.3389/fenrg.2018.00026

Gonzalez Cruz, C., Naderpour, M., \& Ramezani, F. (2018). Water resource selection and optimisation for shale gas developments in Australia: A combinatorial approach. Computers and Industrial Engineering, 124(May), 1-11. https://doi.org/10.1016/j.cie.2018.07.015

Goswami, A., \& George, A. (2020). No TitleUS Elections 2020: Why is fracking a big deal. https://www.downtoearth.org.in/blog/climate-change/us-elections2020-why-is-fracking-a-big-deal-74089

Griffiths, S. (2017). A review and assessment of energy policy in the Middle East and North Africa region. Energy Policy, 102(December 2016), 249-269. https://doi.org/10.1016/j.enpol.2016.12.023

Guler, B., Çelebi, E., \& Nathwani, J. (2018). A 'Regional Energy Hub’ for achieving a low-carbon energy transition. Energy Policy, 113(November 2017), 376-385. https://doi.org/10.1016/j.enpol.2017.10.044

Guliyev, F. (2020). Trump's “America first” energy policy, contingency and the reconfiguration of the global energy order. Energy Policy, 140(August 2019), 111435. https://doi.org/10.1016/j.enpol.2020.111435

He, L., Chen, Y., \& Li, J. (2018). A three-level framework for balancing the tradeoffs among the energy, water, and air-emission implications within the lifecycle shale gas supply chains. Resources, Conservation and Recycling, 133(July 2017), 206-228. https://doi.org/10.1016/j.resconrec.2018.02.015

Heikkila, T., Berardo, R., Weible, C. M., \& Yi, H. C. : E. S. D. P. in the U. A. A. C. V. of A. C. : E. S. D. P. (2018). A Comparative View of Advocacy Coalitions: Exploring Shale Development Politics in the United States, Argentina, and China. Journal of Comparative Policy Analysis: Research and Practice, 00(00), 1-16. https://doi.org/10.1080/13876988.2017.1405551

Herrera, H. (2020). The legal status of fracking worldwide: An environmental law and human rights perspective. https://gnhre.org/2020/01/06/the-legal-statusof-fracking-worldwide-an-environmental-law-and-human-rights-perspective/

Hess, D. J., \& Renner, M. (2019). Conservative political parties and energy transitions in Europe: Opposition to climate mitigation policies. Renewable and Sustainable Energy Reviews, 104(November 2017), 419-428. https://doi.org/10.1016/j.rser.2019.01.019

House, E. J. (2013). Fractured Fairytales: The Failed Social License for Unconventional Oil and Gas Development (13th ed.). Wyoming Law Review.

Howarth, R. W. (2014). A bridge to nowhere: Methane emissions and the greenhouse gas footprint of natural gas. Energy Science and Engineering, 2(2), 4760. https://doi.org/10.1002/ese3.35

Howarth, R. W., Ingraffea, A., \& Engelder, T. (2011). Should fracking stop? Nature, 477(7364), 271-275. https://doi.org/10.1038/477271a

Howarth, R. W., Santoro, R., \& Ingraffea, A. (2011). Methane and the greenhouse-gas footprint of natural gas from shale formations. Climatic Change, 106(4), 679-690. https://doi.org/10.1007/s10584-011-0061-5

Hudgins, D., \& Lee, J. (2016). Modeling the Expansion of Oil Production in South Texas and Mexico Modeling the Expansion of Oil Production in South Texas. The International Trade Journal, 30(5), 387-414. https://doi.org/10.1080/08853908.2016.1204965

Hultman, N., Rebois, D., Scholten, M., \& Ramig, C. (2011). The greenhouse impact of unconventional gas for electricity generation. Environmental Research Letters, 6(4). https://doi.org/10.1088/1748-9326/6/4/049504 
IEA. (2019). The Role of Gas in Today's Energy Transitions. https://www.iea.org/reports/the-role-of-gas-in-todays-energy-transitions

IGU. (2020). Global Gas Report 2020. In Global Gas Report 2020. https://www.igu.org/app/uploads-wp/2020/08/GGR_2020.pdf

Jenner, S., \& Lamadrid, A. J. (2013). Shale gas vs. coal: Policy implications from environmental impact comparisons of shale gas, conventional gas, and coal on air, water, and land in the United States. Energy Policy, 53, 442-453. https://doi.org/10.1016/j.enpol.2012.11.010

Jin, Y., Behrens, P., Tukker, A., \& Scherer, L. (2019). Water use of electricity technologies: A global meta-analysis. Renewable and Sustainable Energy Reviews, 115(June), 109391. https://doi.org/10.1016/j.rser.2019.109391

Jouvet, P. A., \& De Perthuis, C. (2013). Green growth: From intention to implementation. International Economics, 134, 29-55. https://doi.org/10.1016/j.inteco.2013.05.003

Kerr, R. A. (2010). Do we have the energy for the next transition? Science, 329(5993), 780-781. https://doi.org/10.1126/science.329.5993.780

Khan, M. I., Yasmeen, T., Khan, M. I., Farooq, M., \& Wakeel, M. (2016). Research progress in the development of natural gas as fuel for road vehicles: A bibliographic review (1991-2016). Renewable and Sustainable Energy Reviews, 66, 702-741. https://doi.org/10.1016/j.rser.2016.08.041

Khosrokhavar, R., Griffiths, S., \& Wolf, K. H. (2014). Shale Gas Formations and Their Potential for Carbon Storage: Opportunities and Outlook. Environmental Processes, 1(4), 595-611. https://doi.org/10.1007/s40710-014-0036-4

Kim, Y., \& Blank, S. (2015). US shale revolution and Russia: shifting geopolitics of energy in Europe and Asia. Asia Europe Journal, 13(1), 95-112. https://doi.org/10.1007/s10308-014-0400-z

LaBelle, M. (2017). A state of fracking: Building Poland's national innovation capacity for shale gas. Energy Research and Social Science, 23, 26-35. https://doi.org/10.1016/j.erss.2016.11.003

Lange, M., O’Hagan, A. M., Devoy, R. R. N., Le Tissier, M., \& Cummins, V. (2018). Governance barriers to sustainable energy transitions - Assessing Ireland's capacity towards marine energy futures. Energy Policy, 113(November 2017), 623-632. https://doi.org/10.1016/j.enpol.2017.11.020

Lange, M., Page, G., \& Cummins, V. (2018). Governance challenges of marine renewable energy developments in the U.S. - Creating the enabling conditions for successful project development. Marine Policy, 90(December 2017), 37-46. https://doi.org/10.1016/j.marpol.2018.01.008

Lenhard, L. G., Andersen, S. M., \& Coimbra-Araújo, C. H. (2018). Energy-Environmental Implications Of Shale Gas Exploration In Paraná Hydrological Basin, Brazil. Renewable and Sustainable Energy Reviews, 90(March), 56-69. https://doi.org/10.1016/j.rser.2018.03.042

Lin, B., \& Agyeman, S. (2021). Impact of natural gas consumption on sub-Saharan Africa's $\mathrm{CO}_{2}$ emissions: Evidence and policy perspective. Science of the Total Environment, 760, 143321. https://doi.org/10.1016/j.scitotenv.2020.143321

Liu, J., Li, Z., Luo, D., Duan, X., \& Liu, R. (2020). Shale gas production in China: A regional analysis of subsidies and suggestions for policy. Utilities Policy, 67(September 2019), 101135. https://doi.org/10.1016/j.jup.2020.101135

Liu, R., Wang, J., \& Lin, L. (2021). The Extractive Industries and Society Water scarcity footprint assessment for China's shale gas development. The Extractive Industries and Society, 8(2), 100892. https://doi.org/10.1016/j.exis.2021.02.012

Lozano-Maya, J. R. (2016). Shale Gas Development Within the Global Energy Transition: Friend or Foe? https://www.atlanticcouncil.org/blogs/newatlanticist/shale-gas-development-within-the-global-energy-transition-friend-or-foe/

Markovska, N., Taseska, V., \& Pop-Jordanov, J. (2009). SWOT analyses of the national energy sector for sustainable energy development. Energy, 34(6), 752-756. https://doi.org/10.1016/j.energy.2009.02.006

Melikoglu, M. (2014). Shale gas: Analysis of its role in the global energy market. Renewable and Sustainable Energy Reviews, 37, 460-468. https://doi.org/10.1016/j.rser.2014.05.002

Mendelevitch, R., Hauenstein, C., \& Holz, F. (2019). Climate Policy The death spiral of coal in the U.S.: will changes in U.S. Policy turn the tide? The death spiral of coal in the U.S.: will changes in U.S. Policy turn the tide? Technology. https://doi.org/10.1080/14693062.2019.1641462

Mendhe, V. A., Mishra, S., Varma, A. K., Kamble, A. D., Bannerjee, M., \& Sutay, T. (2017). Gas reservoir characteristics of the Lower Gondwana Shales in Raniganj Basin of Eastern India. Journal of Petroleum Science and Engineering, 149(45), 649-664. https://doi.org/10.1016/j.petrol.2016.11.008

Morrissey, J., Schwaller, E., Dickson, D., \& Axon, S. (2020). Affordability, security, sustainability? Grassroots community energy visions from Liverpool, United Kingdom. Energy Research and Social Science, 70(January), 101698. https://doi.org/10.1016/j.erss.2020.101698

NRCan. (2017a). Alberta's Shale and Tight Resources. https://www.nrcan.gc.ca/our-natural-resources/energy-sources-distribution/clean-fossil-fuels/naturalgas/shale-and-tight-resources-canada/albertas-shale-and-tight-resources/17679

NRCan. (2017b). British Columbia’s Shale and Tight Resources.

Oduro Appiah, J., Opio, C., \& Donnelly, S. (2020). Quantifying, comparing, and contrasting forest change pattern from shale gas infrastructure development in the British Columbia's shale gas plays. International Journal of Sustainable Development and World Ecology, 27(2), 114-128. https://doi.org/10.1080/13504509.2019.1649313

Ogden, J., Jaffe, A. M., Scheitrum, D., McDonald, Z., \& Miller, M. (2018). Natural gas as a bridge to hydrogen transportation fuel: Insights from the literature. Energy Policy, 115(February 2017), 317-329. https://doi.org/10.1016/j.enpol.2017.12.049 
ONGC. (2021). Shale gas. https:/www.ongcindia.com/wps/wcm/connect/en/about-ongc/new-initiatives-in-energy/shale-gas/

Osborn, S. G., Vengosh, A., Warner, N. R., \& Jackson, R. B. (2011). Methane contamination of drinking water accompanying gas-well drilling and hydraulic fracturing. Proceedings of the National Academy of Sciences of the United States of America, 108(20), 8172-8176. https://doi.org/10.1073/pnas.1100682108

Perlaviciute, G., \& Steg, L. (2014). Contextual and psychological factors shaping evaluations and acceptability of energy alternatives: Integrated review and research agenda. Renewable and Sustainable Energy Reviews, 35, 361-381. https://doi.org/10.1016/j.rser.2014.04.003

Qin, Y., Tong, F., Yang, G., \& Mauzerall, D. L. (2018). Challenges of using natural gas as a carbon mitigation option in China. Energy Policy, 117(July 2017), 457-462. https://doi.org/10.1016/j.enpol.2018.03.004

Quitzow, R., Bersalli, G., Eicke, L., Jahn, J., Lilliestam, J., Lira, F., Marian, A., Süsser, D., Thapar, S., Weko, S., Williams, S., \& Xue, B. (2021). The COVID-19 crisis deepens the gulf between leaders and laggards in the global energy transition. Energy Research and Social Science, 74, 101981. https://doi.org/10.1016/j.erss.2021.101981

Rasch, E. D. D., \& Köhne, M. (2017). Practices and imaginations of energy justice in transition. A case study of the Noordoostpolder, the Netherlands. Energy Policy, 107(November 2016), 607-614. https://doi.org/10.1016/j.enpol.2017.03.037

Rasch, E. D., \& Köhne, M. (2016). Hydraulic fracturing, energy transition and political engagement in the Netherlands: The energetics of citizenship. Energy Research and Social Science, 13, 106-115. https://doi.org/10.1016/j.erss.2015.12.014

Raza, A., Meiyu, G., Gholami, R., Rezaee, R., Rasouli, V., Sarmadivaleh, M., \& Bhatti, A. A. (2018). Shale gas: A solution for energy crisis and lower CO emission in Pakistan. Energy Sources, Part A: Recovery, Utilization and Environmental Effects, 40(13), 1647-1656. https://doi.org/10.1080/15567036.2018.1486486

Ritchie, H. (2017). How long before we run out of fossil fuels? Our World in Data. https://ourworldindata.org/how-long-before-we-run-out-of-fossil-fuels

Roddis, P., Carver, S., Dallimer, M., \& Ziv, G. (2019). Accounting for taste? Analysing diverging public support for energy sources in Great Britain. Energy Research and Social Science, 56(July), 101226. https://doi.org/10.1016/j.erss.2019.101226

Santos-Alamillos, F. J., Archer, C. L., Noel, L., Budischak, C., \& Facciolo, W. (2017). Assessing the economic feasibility of the gradual decarbonization of a large electric power system. Journal of Cleaner Production, 147, 130-141. https://doi.org/10.1016/j.jclepro.2017.01.097

Scott, S. (2013). Who Shale Regulate the Fracking Industry. Villanova Environmental Law Journal, 24(1), $189-223$.

SGU. (2020). Shale gas. https://www.sgu.se/en/physical-planning/energy/shale-gas/

Sica, C. E., \& Huber, M. (2017). "We Can't Be Dependent on Anybody": The rhetoric of "Energy Independence" and the legitimation of fracking in Pennsylvania. Extractive Industries and Society, 4(2), 337-343. https://doi.org/10.1016/j.exis.2017.02.003

Sovacool, B. K. (2014). Cornucopia or curse? Reviewing the costs and benefits of shale gas hydraulic fracturing (fracking). Renewable and Sustainable Energy Reviews, 37, 249-264. https://doi.org/10.1016/j.rser.2014.04.068

Stephenson, M. (2018). Artificial Global Warming: The 'Fossil Economy.' In Energy and Climate Change. https://doi.org/10.1016/b978-0-12-8120217.00003-8

Tanaka, N. (2013). Big Bang in Japan's energy policy. Energy Strategy Reviews, 1(4), 243-246. https://doi.org/10.1016/j.esr.2013.03.005

The Academy of Medicine Engineering and Science of Texas. (2017). Environmental and Community Impacts fo Shale Development in Texas. TX. https://doi.org/10.25238/TAMESTstf.6.2017

The Council of Canadians. (2014). A Fractivist's Toolkit. https://canadians.org/fracktivists

The Guardian. (2017). France bans fracking and oil extraction in all of its territories. https://www.theguardian.com/environment/2017/dec/20/france-bansfracking-and-oil-extraction-in-all-of-its-territories

Thomas, M., Pidgeon, N., \& Bradshaw, M. (2018). Shale development in the US and Canada: A review of engagement practice. Extractive Industries and Society, 5(4), 557-569. https://doi.org/10.1016/j.exis.2018.07.011

Thomas, M., Pidgeon, N., Evensen, D., Partridge, T., Hasell, A., Enders, C., Herr Harthorn, B., \& Bradshaw, M. (2017). Public perceptions of hydraulic fracturing for shale gas and oil in the United States and Canada. Wiley Interdisciplinary Reviews: Climate Change, 8(3), 1-19. https://doi.org/10.1002/wcc.450

Van de Graaf, T., Haesebrouck, T., \& Debaere, P. (2018). Fractured politics? The comparative regulation of shale gas in Europe. Journal of European Public Policy, 25(9), 1276-1293. https://doi.org/10.1080/13501763.2017.1301985

Varela, V. B. (2020). What's Next for Fracking Under Biden? https://www.cfr.org/in-brief/whats-next-fracking-under-biden

Wachs, E., \& Engel, B. (2021). Land use for United States power generation: A critical review of existing metrics with suggestions for going forward. Renewable and Sustainable Energy Reviews, 143(January 2020), 110911. https://doi.org/10.1016/j.rser.2021.110911

Wagner, A. (2015). Shale gas: Energy innovation in a (non-)knowledge society: A press discourse analysis. Science and Public Policy, 42(2), 273-286. https://doi.org/10.1093/scipol/scu050

Wang, J., Ryan, D., \& Anthony, E. J. (2011). Reducing the greenhouse gas footprint of shale gas. Energy Policy, 39(12), 8196-8199. https://doi.org/10.1016/j.enpol.2011.10.013 
Research, Society and Development, v. 11, n. 3, e3211326282, 2022

(CC BY 4.0) | ISSN 2525-3409 | DOI: http://dx.doi.org/10.33448/rsd-v11i3.26282

Wang, Z., Wennersten, R., \& Sun, Q. (2017). Outline of principles for building scenarios - Transition toward more sustainable energy systems. Applied Energy, 185, 1890-1898. https://doi.org/10.1016/j.apenergy.2015.12.062

Weijermars, R., Clint, O., \& Pyle, I. (2014). Competing and partnering for resources and profits: Strategic shifts ofoil Majors during the past quarter of a century. Energy Strategy Reviews, 3(C), 72-87. https://doi.org/10.1016/j.esr.2014.05.001

Wu, K., Paranjothi, G., Milford, J. B., \& Kreith, F. (2016). Transition to sustainability with natural gas from fracking. Sustainable Energy Technologies and Assessments, 14, 26-34. https://doi.org/10.1016/j.seta.2016.01.003

Wu, X., Xia, J., Guan, B., Liu, P., Ning, L., Yi, X., Yang, L., \& Hu, S. (2019). Water scarcity assessment based on estimated ultimate energy recovery and water footprint framework during shale gas production in the Changning play. Journal of Cleaner Production, 241 , 118312. https://doi.org/10.1016/j.jclepro.2019.118312

Xu, Y. (2020). Will energy transitions impact financial systems? Energy, 194, 116910. https://doi.org/10.1016/j.energy.2020.116910 